\title{
P4-247
}

[C3.3-4] Soil Management Strategy for Enhancing Crop Yields

\section{Nutrient Uptake and Use Efficiency by Tropical Legume Cover Crops at Varying Ph of an Oxisol}

\author{
Nand Kumar Fageria and Adriano Stephan Nascente ${ }^{\star}$
}

National Rice and Bean Research Center of EMBRAPA, Caixa Postal 179, Santo Antonio de Goias, GO, CEP 75375-000, Brazil adriano.nascente@embrapa.br

Oxisols comprise large soil group in tropical America. These soils are acidic and having low fertility. Use of tropical legume cover crops in cropping systems is an important strategy to improve fertility of these soils for sustainable crop production. Data are limited on nutrient uptake and use efficiency of tropical cover crops under different acidity levels. The objective of our study was to evaluate growth and nutrient uptake parameters of 16 tropical legume cover crops under three soil $\mathrm{pH}(5.1,6.5$, and 7.0$)$ of an Oxisol. Shoot dry weight was influenced significantly by $\mathrm{pH}$ and cover crop treatments and their interactions, indicating that cover crops used had differential responses to changing soil $\mathrm{pH}$ levels. Overall, shoot dry weight decreased when soil $\mathrm{pH}$ was raised from 5.1 to 7.0, indicating acidity tolerance of cover crops. Nutrient concentration (content per unit of dry weight), uptake (concentration $\mathrm{X}$ dry weight) and nutrient use efficiency (dry weight of shoot per unit of nutrient uptake) varied significantly among cover crops. The variation in nutrient uptake and use efficiency among cover crop species was associated with variation in shoot dry matter production. Significant variation among crop species in dry matter production and low C/N ratio (average value of 14.25) suggest that cover crops which produced higher dry matter yield like white jack bean, gray mucuna bean, black mucuna bean, mucuna bean ana, and lablab are important choices for planting in tropical soils to recover large amount of macro and micro nutrients and prevent in their leaching in soil plant systems.

Keywords : Plant nutrition, Cerrado, shoot dry matter, C/N ratio 